\title{
SOIL WATER RETENTION AND $S$ INDEX AFTER CROP ROTATION AND CHISELING ${ }^{(1)}$
}

\author{
Juliano Carlos Calonego ${ }^{(2)}$ \& Ciro Antonio Rosolem ${ }^{(3)}$ \\ SUMMARY
}

Soil compaction can be minimized either mechanically or biologically, using plant species with vigorous root systems. An experiment was carried out with soybean (Glycine max) in rotation with triticale (X Triticosecale) and sunflower (Helianthus annuus) in fall-winter associated with pearl millet (Pennisetum glaucum), grain sorghum (Sorghum bicolor) or sunn hemp (Crotalaria juncea) in spring. Crop rotation under no-till was compared with mechanical chiseling. The experiment was carried out in Botucatu, São Paulo State, Brazil. Soil quality was estimated using the $S$ index and soil water retention curves (in the layers of $0-0.05$, 0.075-0.125, 0.15-0.20, 0.275-0.325, and 0.475-0.525 $\mathrm{m}$ deep). Crop rotation and chiseling improved soil quality, increasing the $\mathrm{S}$ index to over 0.035 to a depth of $20 \mathrm{~cm}$ in the soil profile. The improved soil quality, as shown by the $S$ index, makes the use of mechanical chiseling unnecessary, since after 3 years the soil physical quality under no-tilled crop rotation and chiseling was similar.

Index terms: cropping systems, soil compaction, tillage, soil quality

\section{RESUMO: RETENÇÃO DE ÁGUA NO SOLO E ÍNDICE S INFLUENCIADOS POR ROTAÇÃO DE CULTURAS E ESCARIFICAÇÃO}

A compactação do solo pode ser corrigida mecanicamente ou usando espécies vegetais com sistema radicular vigoroso. Um experimento foi conduzido com soja (Glycine max) em rotação com triticale ( $X$ Triticosecale) e girassol (Helianthus annuus) cultivados no outono/ inverno, associados com milheto (Pennisetum glaucum), sorgo (Sorghum bicolor) ou crotalária (Crotalaria juncea) cultivados na primavera. Rotações sob semeadura direta foram comparadas com um tratamento com escarificação no início do experimento. A qualidade do solo foi estimada usando-se o índice $S$ e as curvas de retenção de água do solo nas profundidades

\footnotetext{
(1) Part of the PhD thesis of first author. Received for publication in October 29, 2010 and approved September 15, 2011.

(2) Center of Agricultural Sciences, UNOESTE, CEP 19067-175 Presidente Prudente (SP), Brazil. E-mail: juliano@unoeste.br

(3) Corresponding author, Department of Crop Science, College of Agricultural Sciences, São Paulo State University, Botucatu (SP), Brazil. E-mail: rosolem@fca.unesp.br
} 


\begin{abstract}
de 0-0,05, 0,075-0,15, 0,15-0,20,0,275-0,325 e 0,475-0,525 m. As rotações de culturas e a escarificação melhoraram a qualidade do solo, aumentando o índice $S$ acima de 0,035 até 0,20 m no perfil do solo. Entretanto, a melhoria na qualidade do solo, conforme determinada por meio do indice $S$, não justifica o uso de escarificação mecânica, uma vez que as parcelas sob rotação de culturas em semeadura direta mostraram qualidade física do solo semelhante após três anos.
\end{abstract}

Termos de indexação: sistemas de produção, compactação, manejo do solo, qualidade do solo.

\section{INTRODUCTION}

The development of compacted layers in agricultural areas, caused either by external pressure of machine or animal traffic (Lima et al., 2004) or by natural soil particle consolidation (Dias Jr., 2000), has become a common problem (Andreola et al., 2000; Spera et al., 2004). A possibility to improve the soil structural quality would be the use of crop rotation of species with vigorous root systems, able to grow through soil layers with high penetration resistance, and creating pores through which the next crop roots can grow (Silva \& Rosolem, 2001). Cover crops are species planted before or after cash crops to keep nutrients from leaching, soil from eroding, and land from being overgrown by weeds. Important benefits have been observed in soil structure, both in the short and long term, when cover crops with voluminous and aggressive root systems are used (Dias Jr., 2000).

An adequate assessment of the soil physical quality should include different properties that characterize the physical environment plants are exposed to (Silva et al., 1994). Dexter (2004) considered that the soil water retention curve (WRC) could be used as an indicator of soil physical quality, and therefore proposed the $S$ index. The $S$ index corresponds to the angular coefficient (slope of the tangent) at the inflection point of the retention curve that can be fitted using the model proposed by van Genuchten (1980). Several soil properties such as texture, compaction, organic matter content and root growth were correlated with the $S$ index, and it was concluded that $S<0.020$ indicates soil with high physical restriction, $0.025<S<0.035$ indicates unfavorable and $S>0.035$ favorable soil conditions for root growth (Dexter, 2004). For Andrade \& Stone (2009), the threshold of $S=0.045$ seems to be appropriate to separate soils with good structural conditions from degraded soils, while $S \leq$ 0.025 identifies soils with complete physical degradation. Tormena et al. (2008) and Cavalieri et al. (2009) also found a direct relationship between increasing soil density and reduction in $S$ index. Andrade \& Stone (2009) reported a positive correlation between macroporosity and the $S$ index as well, independent of the soil texture class, showing that this is an appropriate indicator of soil physical quality. Thus, the objective of this study was to determine the effect of crop rotation of cover crop species in no-till and chiseling on soil water retention curves and on the improvement in soil physical quality, as determined by the $S$ index.

\section{MATERIAL AND METHODS}

The experiment was carried out in Botucatu, State of São Paulo, Brazil, from 2003 to 2006, on a clayey Rhodic Nitosol (FAO, 1990) or "Nitossolo Vermelho" distroférrico (Embrapa, 2006), in an area (2249' S, $48^{\circ} 25^{\prime} \mathrm{W} ; 786 \mathrm{~m}$ asl) where soybean/black oat/corn/ triticale had been sown in no-tillage rotation as of 1997 . The climate was classified (Köppen, 1931) as CWa, i.e, a subtropical, humid climate with dry winters. The dry season from May to September is well-defined. Mean rainfall is approximately $1400 \mathrm{~mm}$, the highest monthly mean temperature is over $22^{\circ} \mathrm{C}$ and the lowest below $18^{\circ} \mathrm{C}$. Before the experiment began in April 2003, a $1 \mathrm{~m}$ deep trench was opened, and a compacted layer was detected $0.05-0.20 \mathrm{~m}$ deep. The soil was sampled for chemical (Raij et al., 2001) and physical analyses (Smith \& Mullins, 1991) (Table 1 and Figure 1). Soil mechanical penetration resistance (PR) was evaluated throughout the profile using an electronic penetrograph.

Treatments consisted of the crops triticale (X Triticosecale Wittmack) and sunflower (Helianthus annuus) in the fall-winter period, combined with pearl millet (Pennisetum glaucum L., var. BN-2), forage sorghum (Sorghum bicolor (L.) Moench) and sunn hemp (Crotalaria juncea L.) in the spring as cover crops, and an additional treatment with chiseling, all of which preceded soybean (Glycine max L., Merrill), var. Embrapa 48. This crop sequence was repeated from 2003 to 2006. Mechanical chiseling was carried out in September 2003 using a chisel plow with seven shanks set on two bars and spaced $0.60 \mathrm{~m}$ from each other, resulting in an effective $0.30 \mathrm{~m}$ between-drill spacing. The shanks were inclined forward forming a $25^{\circ}$ angle with an effective action depth of around $0.30 \mathrm{~m}$. A cylinder was attached to the equipment to break up the biggest clods and smooth the soil surface in order to avoid harrowing. The soil was chiseled on only one occasion, that is, after harvesting the fall-winter crops in the first year (September 2003); these plots were left fallow between the winter and summer crops. 
Table 1. Selected chemical and physical properties of the Rhodic Nitosol at the beginning of the experiment

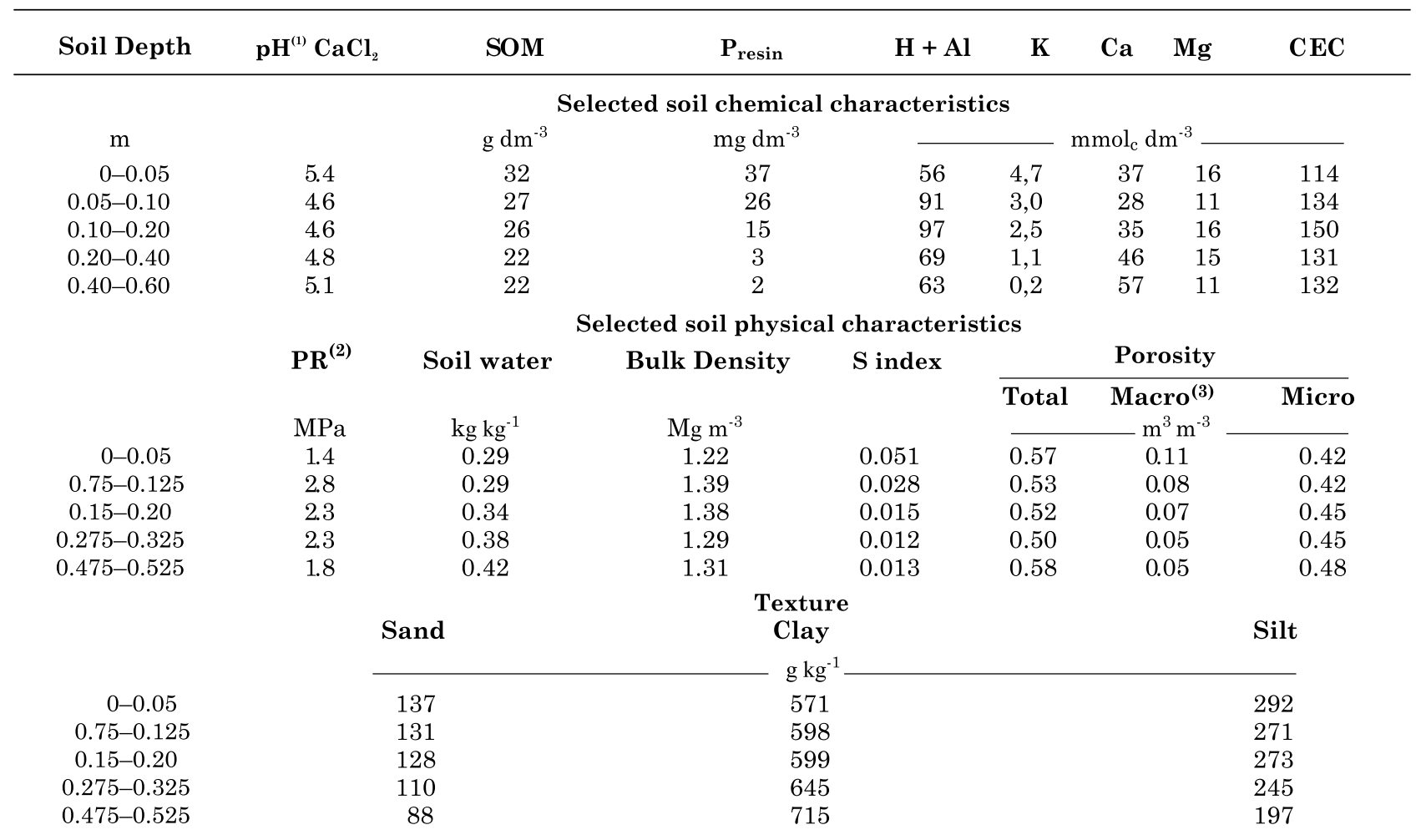

(1) $\mathrm{pH}$ determined in $\mathrm{CaCl}_{2} 0.01 \mathrm{~mol} \mathrm{~L}^{-1}$. (2) Soil mechanical penetration resistance. ${ }^{(3)}$ Macroporosity drained at a matric potential of $-60 \mathrm{hPa}$.

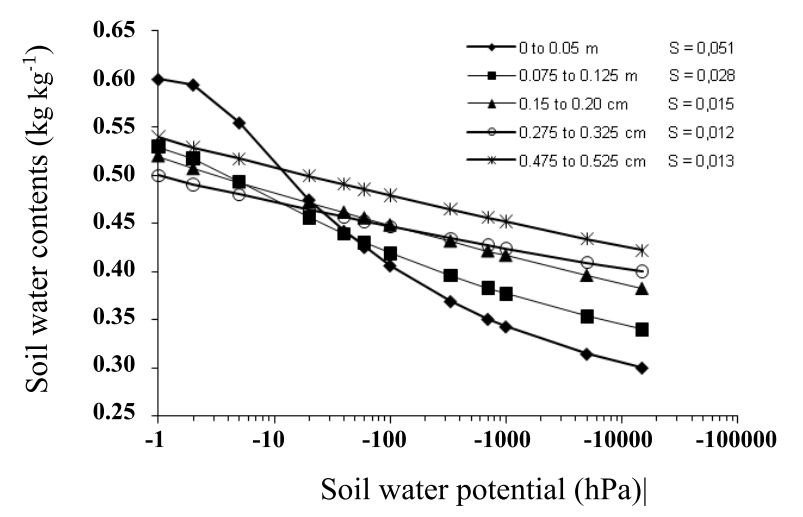

Figure 1. Soil water retention and $S$ indices at the time the experiment was started, as affected by soil depth.

The experiment was set up in a randomized complete blocks in a split-plot design with four replications. Triticale and sunflower were planted on the main plots. Subplots were cropped to pearl millet, forage sorghum and sunn hemp or were mechanicaly chiseled. Sunflower rows were spaced $0.51 \mathrm{~m}$, and triticale $0.17 \mathrm{~m}$ apart. Pearl millet, sorghum and sunn hemp rows were spaced $0.17 \mathrm{~m}$ apart. Soybean was planted in rows spaced $0.45 \mathrm{~m}$ and fertilized with $\mathrm{P}$ and $\mathrm{K}$. Sunflower and triticale were not fertilized and the cover crop species were fertilized at planting with $40 \mathrm{~kg} \mathrm{ha}^{-1} \mathrm{~N}$ (urea).
Undisturbed soil was sampled prior to the experiment (in April 2003) and prior to soybean sowing in the first and third year of the experiment (before soybean sowing). Trenches $(0.30 \times 0.60 \mathrm{~m}$, depth $0.60 \mathrm{~m}$ ) were dug and samples collected from the walls (layers 0-0.05, 0.075-0.125, 0.15-0.20, 0.275-0.325, and $0.475-0.525 \mathrm{~m}$ ) using volumetric cylinders (height $0.050 \mathrm{~m}$, internal diameter $0.048 \mathrm{~m}$ ). Immediately after sampling, the cylinders were sealed with plastic lids. The characteristic soil water retention curves (WRC) were determined as proposed by Embrapa (1997). Briefly, undisturbed soil samples were placed on plastic trays with water to saturate. After saturation, they were subjected to tensions of 20, 40, $60,100,333,1000,5000$, and $15000 \mathrm{hPa}$. A tension table was used to obtain matric potentials ( $\Psi \mathrm{m})$ of $-20,-40$ and $-60 \mathrm{hPa}$, and matric potentials of -100 , $-333,-1000,-5000$, and $-15000 \mathrm{hPa}$ were obtained using a Richards chamber (Klute, 1986). The amount of water retained in the soil at each potential was determined by weighing the samples at the saturation point and when hydraulic equilibrium was reached.

After the water had been extracted at $15000 \mathrm{hPa}$, the sample was weighed and dried at $105^{\circ} \mathrm{C}$ for $48 \mathrm{~h}$ in a forced air oven. Then the dry weight of the samples was determined. After obtaining the gravimetric moisture at each matric potential, the WRC was determined by fitting the original data to 
the function (Equation 1) proposed by van Genuchten (1980). The equation considers the matric potential ( $\Psi)$ as independent and the gravimetric moisture $(\theta)$ as dependent variable.

$$
\theta=\theta \mathrm{r}+\left((\theta \mathrm{s}-\theta \mathrm{r}) /\left(1+(\alpha \Psi)^{\mathrm{n}}\right)^{1-1 / \mathrm{n}}\right)
$$

where $\theta=$ soil gravimetric moisture at each matric potential $\left(\mathrm{kg} \mathrm{kg}^{-1}\right) ; \theta_{\mathrm{r}}=$ soil gravimetric moisture at the matric potential of $-15000 \mathrm{hPa}\left(\mathrm{kg} \mathrm{kg}^{-1}\right) ; \theta_{\mathrm{s}}=$ saturated soil gravimetric moisture $\left(\mathrm{kg} \mathrm{kg}^{-1}\right) ; \Psi=$ matric potential $(\mathrm{hPa}) ; \alpha, \mathrm{n}=$ coefficients of the equation.

The $\mathrm{S}$ index, i.e., the angular coefficient of the soil water retention curve, was determined using equation 2, which is derived from equation 1 as proposed by Dexter (2004). The index $S$ modulus was used to discuss the results.

$$
\mathrm{S}=-\mathrm{n}(\theta \mathrm{s}-\theta \mathrm{r}))((2 \mathrm{n}-1) /(\mathrm{n}-1))^{((1 / \mathrm{n})-2)}
$$

where $\mathrm{S}=$ angular coefficient of the water retention curve at the inflection point; $\theta_{\mathrm{r}}=$ soil gravimetric moisture at the matric potential $-15000 \mathrm{hPa}\left(\mathrm{kg} \mathrm{kg}^{-1}\right)$; $\theta_{\mathrm{S}}=$ saturated soil gravimetric moisture $\left(\mathrm{kg} \mathrm{kg}^{-1}\right) ; \mathrm{n}$ $=$ coefficient of the water retention curve in the soil (Equation 1).

The water retention curves were fit using SWRC software (Dourado Neto et al., 1990) and tested using the $\mathrm{F}$ test $(\mathrm{p}<0.05)$ (Tables 2 e 3$)$.

\section{RESULTS AND DISCUSSION}

The soil of the experimental area was structurally degraded in the subsurface below $0.075 \mathrm{~m}$, causing physical restrictions for root growth in the profile (Dexter, 2004). The physical restrictions resulted from the high penetration resistance $(\mathrm{PR})$, soil bulk density (BD), and macroporosity below $0.10 \mathrm{~m}^{3} \mathrm{~m}^{-3}$ (Table 1), considered limiting for optimum plant growth, and the angular coefficient $(S)$ below 0.035 (Figure 1).

The highest soil water retention between saturation and $-60 \mathrm{hPa}$ in the $0-0.05 \mathrm{~m}$ layer was observed after the triticale plus pearl millet treatment (Figure 2a), at the end of the first year of the experiment, indicating higher total porosity and macroporosity (Reichardt \& Timm, 2004). According to Reeve \& Carter (1991), compacted soils are characterized by lower water retention at low tensions (0 to $100 \mathrm{hPa}$ ), resulting from decreased porosity, mainly of the macropores, which are filled with gravitational water at the highest matric potentials (less negative). Conversely, an increase in water retention is usually observed at the lower potentials (more negative) as result of increased micro porosity, increasing the capillary water volume. Therefore, the water curve of soils with this characteristic has a lower $S$ index, that is, the angle of the tangent passing through the inflection point is smaller (Dexter, 2004).
The water retention curve, in the treatment with triticale and pearl millet, was typical of less compacted soil in 0-0.05 m (Reichardt \& Timm, 2004) and had the greatest $S$ value, i.e., $S=0.051$, similar to the value of 0.055 obtained by Cavalieri et al. (2009) in the $0-0.10 \mathrm{~m}$ layer in a soil under long-term no-tillage in Paraná, Brazil. The only treatment resulting in an $S$ index lower than 0.035 was sunflower and sorghum (Figure 3a). Dexter (2004) concluded that the $S$ index was directly and indirectly related with soil organic matter and soil compaction, respectively. Thus, a higher $S$ index value indicates a better soil structural quality.

Greater water retention at low tensions was observed again by the WRC in the triticale plus pearl millet treatment, in the layer $0.075-0.125 \mathrm{~m}$ (Figure 2b), indicating a greater volume of macropores. At this depth, when triticale was planted in chiseled plots, a WRC with characteristics of less compacted soil was also observed. Saturated soil moisture was highest in this treatment, in other words, total porosity was greatest, water retention at medium and high tensions lower (over $100 \mathrm{hPa}$ ) and the proportion of micropores decreased. Another indication of minimized soil compaction in plots with this treatment was the lower water retention at the permanent wilting point (PWP), that is, at the $-15000 \mathrm{hPa}$ matric potential. An increase in soil bulk density may increase water retained at the PWP (Cavalieri et al., 2006) because after exposure to a tension of $15000 \mathrm{hPa}$, the remaining soil water is in a thin film, retained by adsorption (with high energy) around the soil colloids (sheet water).

When the $S$ index was applied to study the soil structural degradation in the $0.075-0.125 \mathrm{~m}$ layer (Figure 3b), it was observed again that triticale plus pearl millet or triticale plus chiseling enhanced the soil physical quality in the very first year of the experiment, since the $\mathbf{S}$ values were highest in these treatments (0.054 and 0.055, respectively).

In the $0.15-0.20 \mathrm{~m}$ soil layer, greater soil compaction was observed in plots with sunflower plus sunn hemp, since the water content was lower in saturated soil (Figure 2c), leading to the lowest $S$ index value 0.017 (Figure 3c), which was very close to that observed in the first year of the experiment, $S=0.015$ (Table 1). According to Dexter (2004), $S$ values below 0.020 are associated with very poor soil physical properties. On the other hand, growing triticale on chiseled plots resulted in a typical WRC of less compacted soils in this layer (Figure 2c). Although it did not increase the soil maximum water retention capacity, this treatment reduced the water retained in micropores, i..e, in matric potentials below $-60 \mathrm{hPa}$. Furthermore, in this treatment the lowest soil moisture was detected at PWP, resulting in a greater $S$ value $(S=0.040)$ in the first year (Figure 3c). For Dexter (2004), an $S$ value of 0.035 is the minimum threshold to characterize good soil structure quality. However, in the tropical soils of Brazil, this condition 
Table 2. Estimated regression coefficients for the water retention curve (WRC) ${ }^{(1)}$ at the at the 0 to $0.05,0.075$ to $0.125,0.15$ to $0.20,0.275$ to 0.325 and 0.475 to $0.525 \mathrm{~m}$ deep soil layers in the first year of the experiment

\begin{tabular}{|c|c|c|c|c|c|}
\hline \multirow{2}{*}{ Treatment } & \multicolumn{4}{|c|}{ Parameter } & \multirow{2}{*}{$\mathbf{R}^{2}$} \\
\hline & $\alpha(2)$ & $n^{(2)}$ & $\theta \mathbf{r}^{(3)}$ & $\theta \mathbf{s}^{(4)}$ & \\
\hline \multicolumn{6}{|c|}{ Depth of 0 to $0.05 \mathrm{~m}$} \\
\hline sunflower + pearl millet & 0.0057 & 0.5698 & 0.300 & 0.561 & $0.999 * *$ \\
\hline sunflower + forage sorghum & 0.0004 & 0.4458 & 0.324 & 0.551 & $0.996^{* *}$ \\
\hline sunflower + sunn hemp & 0.0442 & 0.8400 & 0.289 & 0.559 & $0.999 * *$ \\
\hline sunflower + chiseling & 0.0505 & 1.0037 & 0.248 & 0.542 & $0.996^{* *}$ \\
\hline triticale + pearl millet & 0.0349 & 1.0633 & 0.282 & 0.579 & $0.999^{* *}$ \\
\hline triticale + forage sorghum & 0.0008 & 0.5726 & 0.337 & 0.538 & $0.998^{* *}$ \\
\hline triticale + sunn hemp & 0.0004 & 0.4572 & 0.305 & 0.552 & $0.995^{* *}$ \\
\hline \multirow[t]{2}{*}{ triticale + chiseling } & 0.0256 & 0.7047 & 0.296 & 0.548 & $0.998 * *$ \\
\hline & \multicolumn{4}{|c|}{ Depth of 0.075 to $0.125 \mathrm{~m}$} & \\
\hline sunflower + pearl millet & 0.0006 & 0.4377 & 0.322 & 0.507 & $0.995^{* *}$ \\
\hline sunflower + forage sorghum & 0.0017 & 0.6813 & 0.347 & 0.481 & $0.990^{* *}$ \\
\hline sunflower + sunn hemp & 0.0003 & 0.4276 & 0.345 & 0.512 & $0.995^{* *}$ \\
\hline sunflower + chiseling & 0.0149 & 0.6047 & 0.321 & 0.549 & $0.997 * *$ \\
\hline triticale + pearl millet & 0.0351 & 1.6605 & 0.320 & 0.541 & $0.997 * *$ \\
\hline triticale + forage sorghum & 0.0001 & 0.5501 & 0.339 & 0.499 & $0.995 * *$ \\
\hline triticale + sunn hemp & 0.0001 & 0.5020 & 0.348 & 0.522 & $0.995^{* *}$ \\
\hline \multirow[t]{2}{*}{ triticale + chiseling } & 0.2082 & 4.5490 & 0.263 & 0.558 & $0.999 * *$ \\
\hline & \multicolumn{4}{|c|}{ Depth of 0.15 to $0.20 \mathrm{~m}$} & \\
\hline sunflower + pearl millet & 0.0705 & 2.9816 & 0.320 & 0.502 & $0.999 * *$ \\
\hline sunflower + forage sorghum & 0.0026 & 0.7303 & 0.368 & 0.500 & $0.995 * *$ \\
\hline sunflower + sunn hemp & 0.0003 & 0.4336 & 0.341 & 0.472 & $0.999^{* *}$ \\
\hline sunflower + chiseling & 0.0003 & 0.4273 & 0.355 & 0.518 & $0.995^{* *}$ \\
\hline triticale + pearl millet & 0.0127 & 0.6872 & 0.340 & 0.531 & $0.984^{* *}$ \\
\hline triticale + forage sorghum & 0.0001 & 0.4419 & 0.349 & 0.530 & $0.998^{* *}$ \\
\hline triticale + sunn hemp & 0.0025 & 0.6170 & 0.367 & 0.522 & $0.995 * *$ \\
\hline \multirow[t]{2}{*}{ triticale + chiseling } & 0.1286 & 4.7978 & 0.275 & 0.499 & $0.997 * *$ \\
\hline & \multicolumn{4}{|c|}{ Depth of 0.275 to $0.325 \mathrm{~m}$} & \\
\hline sunflower + pearl millet & 0.5221 & 2.6039 & 0.291 & 0.520 & $0.995 * *$ \\
\hline sunflower + forage sorghum & 0.2488 & 3.5558 & 0.297 & 0.531 & $0.993^{* *}$ \\
\hline sunflower + sunn hemp & 0.0001 & 0.4059 & 0.368 & 0.539 & $0.996^{* *}$ \\
\hline sunflower + chiseling & 0.1277 & 2.0768 & 0.335 & 0.530 & $0.999 * *$ \\
\hline triticale + pearl millet & 0.0149 & 0.7019 & 0.381 & 0.531 & $0.985^{* *}$ \\
\hline triticale + forage sorghum & 0.0004 & 0.5683 & 0.389 & 0.538 & $0.998 * *$ \\
\hline riticale + sunn hemp & 0.0002 & 0.5265 & 0.389 & 0.529 & $0.998 * *$ \\
\hline \multirow[t]{2}{*}{ triticale + chiseling } & 0.0110 & 0.6301 & 0.357 & 0.540 & $0.999 * *$ \\
\hline & \multicolumn{4}{|c|}{ Depth of 0.475 to $0.525 \mathrm{~m}$} & \\
\hline sunflower + pearl millet & 0.0648 & 0.8882 & 0.359 & 0.560 & $0.996 * *$ \\
\hline sunflower + forage sorghum & 0.0918 & 0.9841 & 0.353 & 0.559 & $0.996 * *$ \\
\hline sunflower + sunn hemp & 0.0377 & 0.8191 & 0.359 & 0.551 & $0.997 * *$ \\
\hline sunflower + chiseling & 0.0426 & 0.7189 & 0.357 & 0.562 & $0.996^{* *}$ \\
\hline triticale + pearl millet & 0.0422 & 0.8210 & 0.357 & 0.559 & $0.983^{* *}$ \\
\hline triticale + forage sorghum & 0.0297 & 0.8110 & 0.368 & 0.565 & $0.998^{* *}$ \\
\hline triticale + sunn hemp & 0.0360 & 0.8737 & 0.367 & 0.550 & $0.997 * *$ \\
\hline triticale + chiseling & 0.0810 & 0.8430 & 0.347 & 0.561 & $0.998 * *$ \\
\hline
\end{tabular}

(1) $\theta=\theta \mathrm{r}+\left((\theta \mathrm{s}-\theta \mathrm{r}) /\left(1+(\alpha \Psi)^{\mathrm{n}}\right)^{1-1 / \mathrm{n}}\right) .{ }^{(2)}$ Regression coefficients. ${ }^{(3)}$ Soil gravimetric moisture at the matric potential of $-15000 \mathrm{hPa}$ $\left(\mathrm{kg} \mathrm{kg}^{-1}\right)$. ${ }^{(4)}$ Saturated soil gravimetric moisture $\left(\mathrm{kg} \mathrm{kg}^{-1}\right) . * *$ : significant at $\mathrm{p}<0.01$.

would only be met with $S$ values over 0.045 (Andrade $\&$ Stone, 2009). The higher $S$ value defined by Andrade \& Stone (2009) was related to the narrower limits for bulk density, macroporosity, total porosity and the relationship between macro and micropores for better plant growth assumed by these authors.

In the $0.275-0.325 \mathrm{~m}$ layer, the WRC observed under triticale plus pearl millet (Figure 2c) characterized a soil with poor structural quality, with the lowest $S$ value, 0.019 (Figure 3d). Thus, it can be inferred that with only one crop of pearl millet in succession to triticale, i.e, a rotation involving only monocotyledonous species, the cultivation effect on the soil structure was limited to the first $0.20 \mathrm{~m}$ of the soil profile.

Treatment effects on the WRC were lower in the $0.475-0.525 \mathrm{~m}$ soil layer (Figure $2 \mathrm{e}$ ) and the $S$ values 
Table 3. Estimated regression coefficients for the water retention curve (WRC) ${ }^{(1)}$ at the 0 to $0.05,0.075$ to $0.125,0.15$ to $0.20,0.275$ to 0.325 and 0.475 to $0.525 \mathrm{~m}$ soil layers in the third year of the experiment

\begin{tabular}{|c|c|c|c|c|c|}
\hline \multirow[b]{2}{*}{ Treatment } & \multicolumn{4}{|c|}{ Parameter } & \multirow[b]{2}{*}{$\mathbf{R}^{2}$} \\
\hline & $\alpha(2)$ & $\mathbf{n}^{(2)}$ & $\theta \mathbf{r}^{(3)}$ & $\theta \mathbf{s}^{(4)}$ & \\
\hline & \multicolumn{4}{|c|}{ Depth of 0 to $0.05 \mathrm{~m}$} & \\
\hline sunflower + pearl millet & 0.1286 & 4.9223 & 0.248 & 0.540 & $0.999 * *$ \\
\hline sunflower + forage sorghum & 0.1354 & 1.4078 & 0.254 & 0.561 & $0.998^{* *}$ \\
\hline sunflower + sunn hemp & 0.1999 & 3.8764 & 0.228 & 0.562 & $0.999^{* * *}$ \\
\hline sunflower + chiseling & 0.0633 & 1.2729 & 0.286 & 0.530 & $0.997^{* *}$ \\
\hline triticale + pearl millet & 0.1624 & 4.6281 & 0.261 & 0.559 & $0.997^{* *}$ \\
\hline triticale + forage sorghum & 0.1368 & 4.3979 & 0.282 & 0.551 & $0.996^{* *}$ \\
\hline triticale + sunn hemp & 0.2412 & 3.9298 & 0.246 & 0.538 & $0.998^{* *}$ \\
\hline \multirow[t]{2}{*}{ triticale + chiseling } & 0.1336 & 2.1075 & 0.271 & 0.511 & 0.997 ** \\
\hline & \multicolumn{4}{|c|}{ Depth of 0.075 to $0.125 \mathrm{~m}$} & \\
\hline sunflower + pearl millet & 0.0342 & 1.0909 & 0.311 & 0.535 & $0.994^{* *}$ \\
\hline sunflower + forage sorghum & $\begin{array}{l}.0042 \\
0.0387\end{array}$ & 1.0441 & 0.306 & 0.525 & $0.987^{* * *}$ \\
\hline sunflower + sunn hemp & 0.0243 & 0.8350 & 0.315 & 0.532 & $0.998^{* *}$ \\
\hline sunflower + chiseling & 0.0482 & 1.2245 & 0.320 & 0.533 & $0.959 * *$ \\
\hline triticale + pearl millet & 0.0514 & 1.8427 & 0.308 & 0.524 & $0.996^{* *}$ \\
\hline triticale + forage sorghum & 0.0357 & 0.8057 & 0.286 & 0.522 & $0.991^{* *}$ \\
\hline triticale + sunn hemp & 0.0678 & 1.0202 & 0.293 & 0.523 & $0.989^{* *}$ \\
\hline \multirow[t]{2}{*}{ triticale + chiseling } & 0.1892 & 1.5847 & 0.239 & 0.525 & $0.978^{* *}$ \\
\hline & \multicolumn{4}{|c|}{ Depth of 0.15 to $0.20 \mathrm{~m}$} & \\
\hline sunflower + pearl millet & 0.0739 & 5.9692 & 0.320 & 0.550 & $0.996^{* *}$ \\
\hline sunflower + forage sorghum & 0.0850 & 2.6235 & 0.312 & 0.549 & $0.992^{* *}$ \\
\hline sunflower + sunn hemp & 0.1386 & 4.8965 & 0.294 & 0.541 & $0.997^{* *}$ \\
\hline sunflower + chiseling & 0.1583 & $\begin{array}{l}4.0700 \\
4.7195\end{array}$ & 0.266 & 0.542 & $0.998^{* *}$ \\
\hline triticale + pearl millet & 0.1231 & 4.9691 & 0.287 & 0.519 & $0.998^{* *}$ \\
\hline triticale + forage sorghum & $\begin{array}{l}0.1231 \\
0.0398\end{array}$ & $\begin{array}{l}4.9691 \\
1.0794\end{array}$ & 0.346 & $\begin{array}{l}0.019 \\
0.561\end{array}$ & $0.996^{* *}$ \\
\hline \multirow{2}{*}{$\begin{array}{l}\text { triticale }+ \text { sunn hemp } \\
\text { triticale + chiseling }\end{array}$} & 0.0994 & 6.2357 & 0.291 & 0.539 & $0.998^{* *}$ \\
\hline & 0.1037 & 5.9319 & 0.304 & 0.531 & $0.997^{* *}$ \\
\hline \multicolumn{5}{|c|}{ Depth of 0.275 to $0.325 \mathrm{~m}$} & \\
\hline sunflower + pearl millet & 00805 & 15954 & 0328 & 0.540 & $0.970 * *$ \\
\hline sunflower + forage sorghum & 0.1130 & 2.0422 & 0.335 & 0.544 & $0.959^{* *}$ \\
\hline sunflower + sunn hemp & 0.1311 & 3.1705 & 0.305 & 0.527 & $0.983^{* *}$ \\
\hline sunflower + chiseling & 0.3986 & 2.7220 & 0.214 & 0.533 & $0.979^{* *}$ \\
\hline triticale + pearl millet & 0.1292 & 1.2261 & 0.276 & 0.526 & $0.984 * *$ \\
\hline triticale + forage sorghum & 0.0985 & 3.6091 & 0.341 & 0.533 & $0.999^{* *}$ \\
\hline riticale + sunn hemp & 0.1817 & 1.1386 & 0.333 & 0.523 & $0.983^{* *}$ \\
\hline \multirow[t]{2}{*}{ triticale + chiseling } & 0.1133 & 2.1742 & 0.316 & 0.534 & $0.979^{* *}$ \\
\hline & \multicolumn{4}{|c|}{ Depth of 0.475 to $0.525 \mathrm{~m}$} & \\
\hline sunflower + pearl millet & 0.0043 & 0.6707 & 0.376 & 0.565 & $0.992^{* *}$ \\
\hline sunflower + forage sorghum & 0.0119 & 0.6845 & 0.354 & 0.551 & $0.998^{* *}$ \\
\hline sunflower + sunn hemp & 0.0031 & 0.5564 & 0.376 & 0.552 & $0.996^{* *}$ \\
\hline sunflower + chiseling & 0.0161 & 0.6580 & 0.344 & 0.569 & $0.996^{* *}$ \\
\hline triticale + pearl millet & 0.0037 & 0.5929 & 0.360 & 0.558 & $0.991^{* *}$ \\
\hline triticale + forage sorghum & 0.0065 & 0.7538 & 0.378 & 0.564 & $0.989 * *$ \\
\hline triticale + sunn hemp & 0.0096 & 0.6709 & 0.364 & 0.551 & $0.998^{* *}$ \\
\hline triticale + chiseling & 0.0133 & 0.7763 & 0.370 & 0.542 & $0.986^{* *}$ \\
\hline
\end{tabular}

(1) $\theta=\theta \mathrm{r}+\left((\theta \mathrm{s}-\theta \mathrm{r}) /\left(1+(\alpha \Psi)^{\mathrm{n}}\right)^{1-1 / \mathrm{n}}\right) .{ }^{(2)}$ Regression coefficients. ${ }^{(3)}$ Soil gravimetric moisture at the matric potential of $-15000 \mathrm{hPa}$ $\left(\mathrm{kg} \mathrm{kg}^{-1}\right)$. ${ }^{(4)}$ Saturated soil gravimetric moisture $\left(\mathrm{kg} \mathrm{kg}^{-1}\right)$. ${ }^{* *}$ : significant at $\mathrm{p}<0.01$.

were generally between 0.031 and 0.035 , characterizing a soil with poor structural quality (Dexter, 2004). However, the values were higher than those determined in the previous year, by the time the experiment began $(S=0.013)$, when the soil structural quality was even worse. This improvement may be a result of the better soil management from the beginning of the experiment.
After three years, $\theta \mathrm{s}$ was lowest in the 0-0.05 m layer with chiseling (Figure 4a). This result may be related to particle reorganization and consolidation, occupying the porous space in the absence of root systems, as argued by Calonego \& Rosolem (2008), based on data from this same experiment. Leaving the area fallow accelerates the compaction process because the absence of plant residues on the surface 


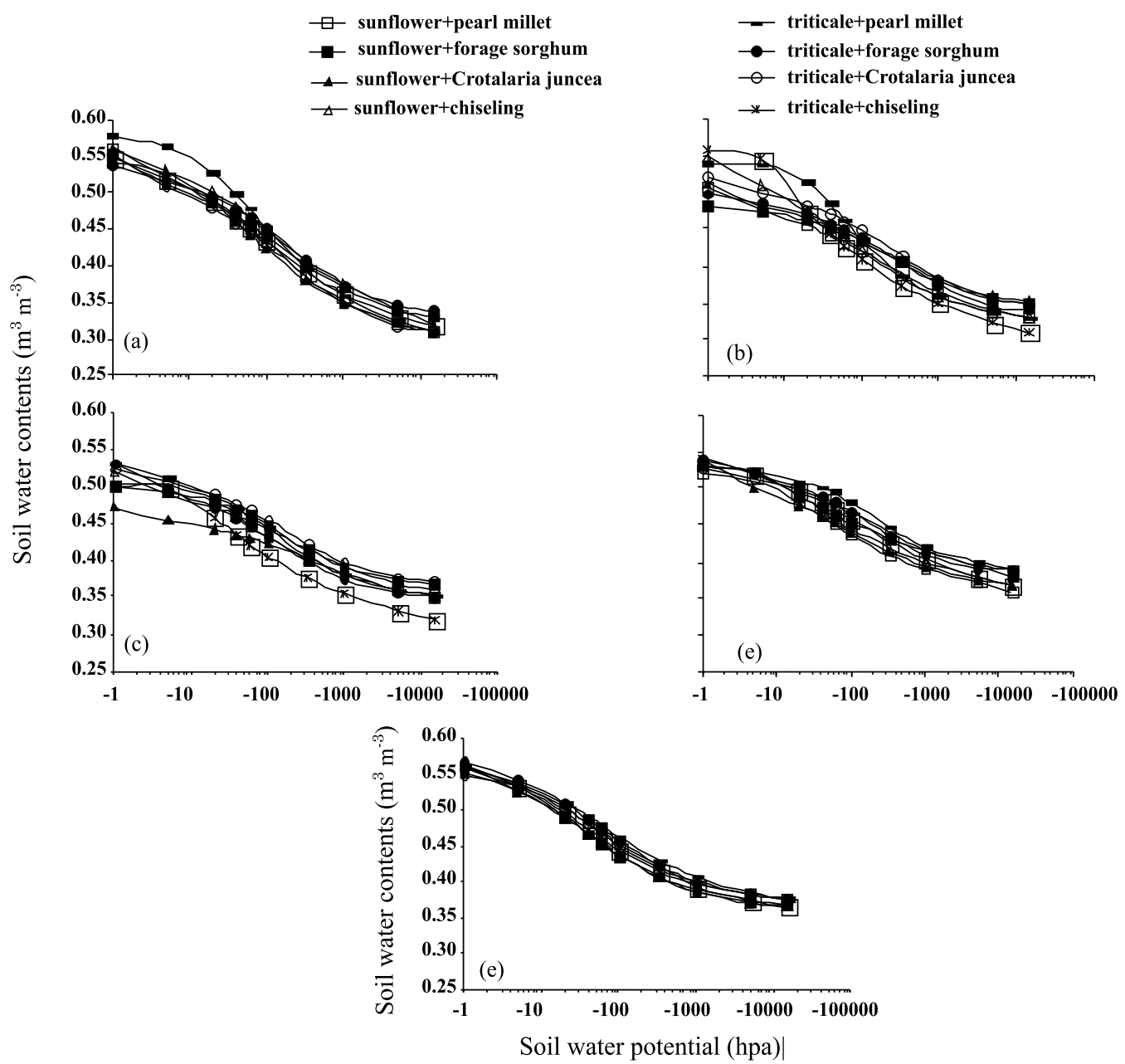

Figure 2. Soil water retention at the end of the first year of the experiment (2003/2004), as affected by crop rotation, chiseling and soil depth. (a) 0-0.05 m; (b) 0.075-0.125 m; (c) 0.15-0.20 m; (d) 0.275-0.325 m and (e) $0.475-0.525 \mathrm{~m}$.

allows the rainfall to reach the soil with high energy. This leads to soil de-structuring and breaking of aggregates that migrate to the first millimeters below the surface (1 and $5 \mathrm{~mm}$ ), where they are inserted into the porous space, forming a layer with high penetration resistance (Schaefer et al., 2002). Furthermore, the absence of roots increases soil susceptibility to compaction because roots play an important role in structuring processes by drawing the particles closer when growing in pores and releasing exudates that act as cement in the formation of macroaggregates. The effect of organic matter on soil structure also affects water retention dynamics since it plays an important role in the formation of stable aggregates, reducing pore space obstruction and increasing the proportion of macropores.

A decrease in water retention at medium and high tensions was observed in the 0-0.05 m layer from year 1 to the end of year 3, (Figures $2 \mathrm{a}$ and $4 \mathrm{a}$ ), suggesting a decrease in the proportion of small pores, which are responsible for retaining water with greater energy. According to Reichardt \& Timm (2004) a gradual increase in tension results in the draining of progressively smaller pores so that at the higher tensions, only very small pores retain water.

The decrease in water content at the highest tension $(15000 \mathrm{hPa})$ in the $0-0.05 \mathrm{~m}$ layer when cover crops where grown (Figure 4a) is a clear evidence of soil structuring and reduced soil compaction. However, there was no increase in the volume of plant-available water (retained at matric potentials between -100 and $-15000 \mathrm{hPa}$ ) because there was also a decrease in the water content retained at field capacity $(-10 \mathrm{hPa})$. This decrease resulted from an increase in the macropore volume, reducing capillary water retention, as similarly reported by Cavalieri et al. (2006). The effects of crop rotation and chiseling on soil organic matter at this site reported by Calonego \& Rosolem (2008) in a previous paper were not significant, varying 


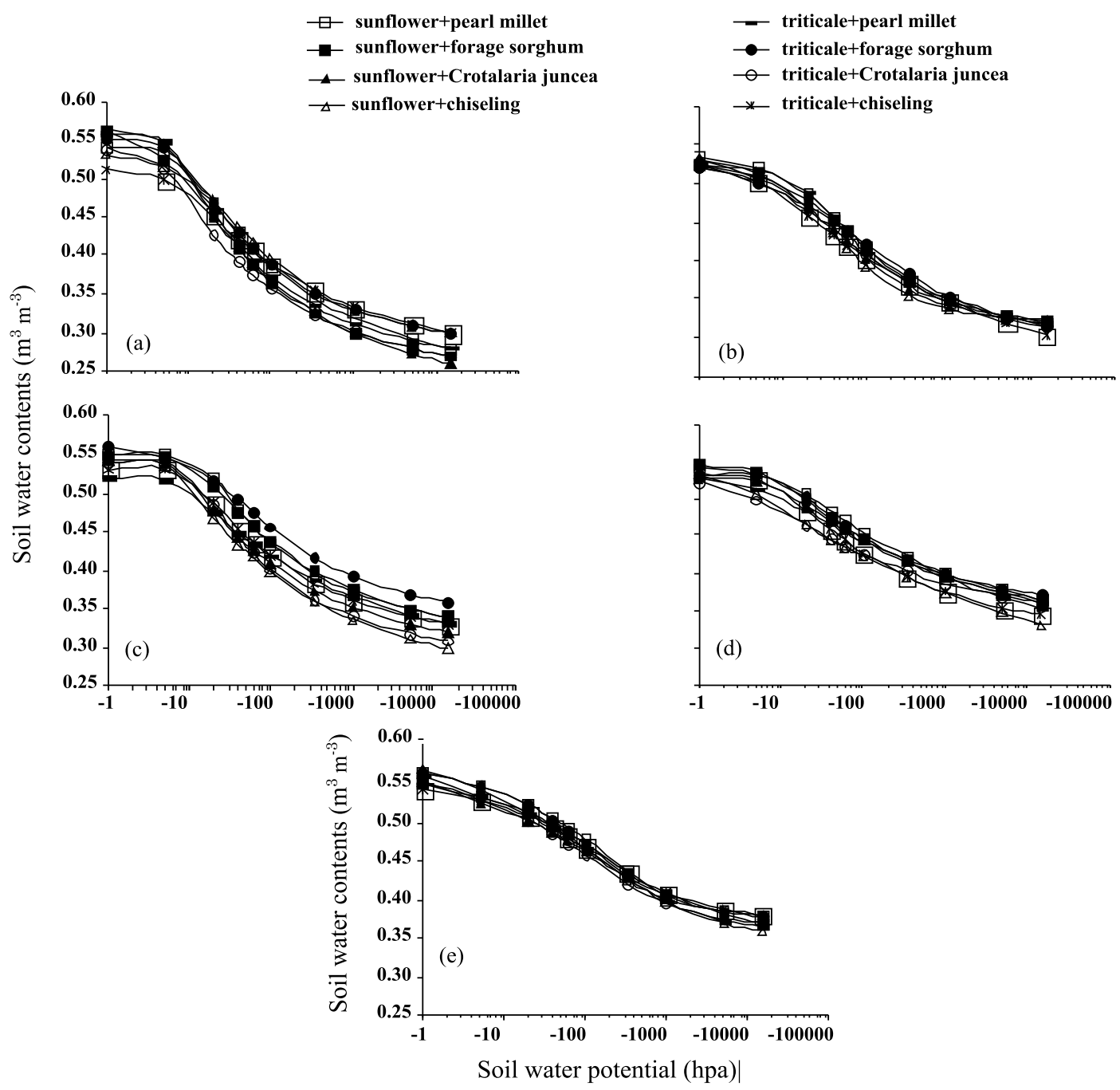

Figure 3. Soil water retention at the end of the third year of the experiment (2005/2006), as affected by crop rotation, chiseling and soil depth. (a) $0-0.05 \mathrm{~m}$; (b) $0.075-0.125 \mathrm{~m}$; (c) $0.15-0.20 \mathrm{~m}$; (d) $0.275-0.325 \mathrm{~m}$ and (e) $0.475-0.525 \mathrm{~m}$.

less than $10 \%$ among treatments, which is not high enough to explain the results observed in this paper.

Thus, after three years of field experimentation it can be inferred that growing cover crops in spring resulted in a WRC indicating a better structured soil in the 0-0.05 m layer, as a result of the cumulative effect of the treatments on soil quality. However, effects of crop rotation on soil quality, increasing soybean yield, can only be observed in the medium and long term, as stated by Calonego \& Rosolem (2010). These results were obtained without considering the fall-winter crop, because $S$ values were greater in treatments including the spring crops (Figure 5a), and the $S$ value was highest $(S=0.08)$ in triticale plus pearl millet. Interestingly, greatest root growth (pearl millet and soybean) was observed in this soil layer, as discussed by Calonego \& Rosolem (2010). Further comparisons of WRC showed that in the first and third year, soil moisture at saturation was increased by cover crops in the 0.075-0.125 m layer (Figure 4b). However, a residual effect of chiseling was observed in the sunflower plus chiseling treatment, since water retention was lower between 60 and $-1000 \mathrm{hPa}$, showing a reduction in the proportion of micropores.

The treatments triticale plus pearl millet and sunflower plus chiseling resulted in the best soil structure in the 0.075-0.125 m layer, reflected by the high $S$ index (0.053 and 0.051 , respectively) (Figure 5b). In contrast, $S$ was only lower than 0.035 for triticale plus sorghum, i.e, poor structural quality, as explained by Dexter (2004).

A residual effect of chiseling on the sunflower plus chiseling treatment was also observed in the $0.15-$ $0.20 \mathrm{~m}$ layer (Figure 4c). At this depth, triticale plus sunn hemp reduced water retention in micropores and 


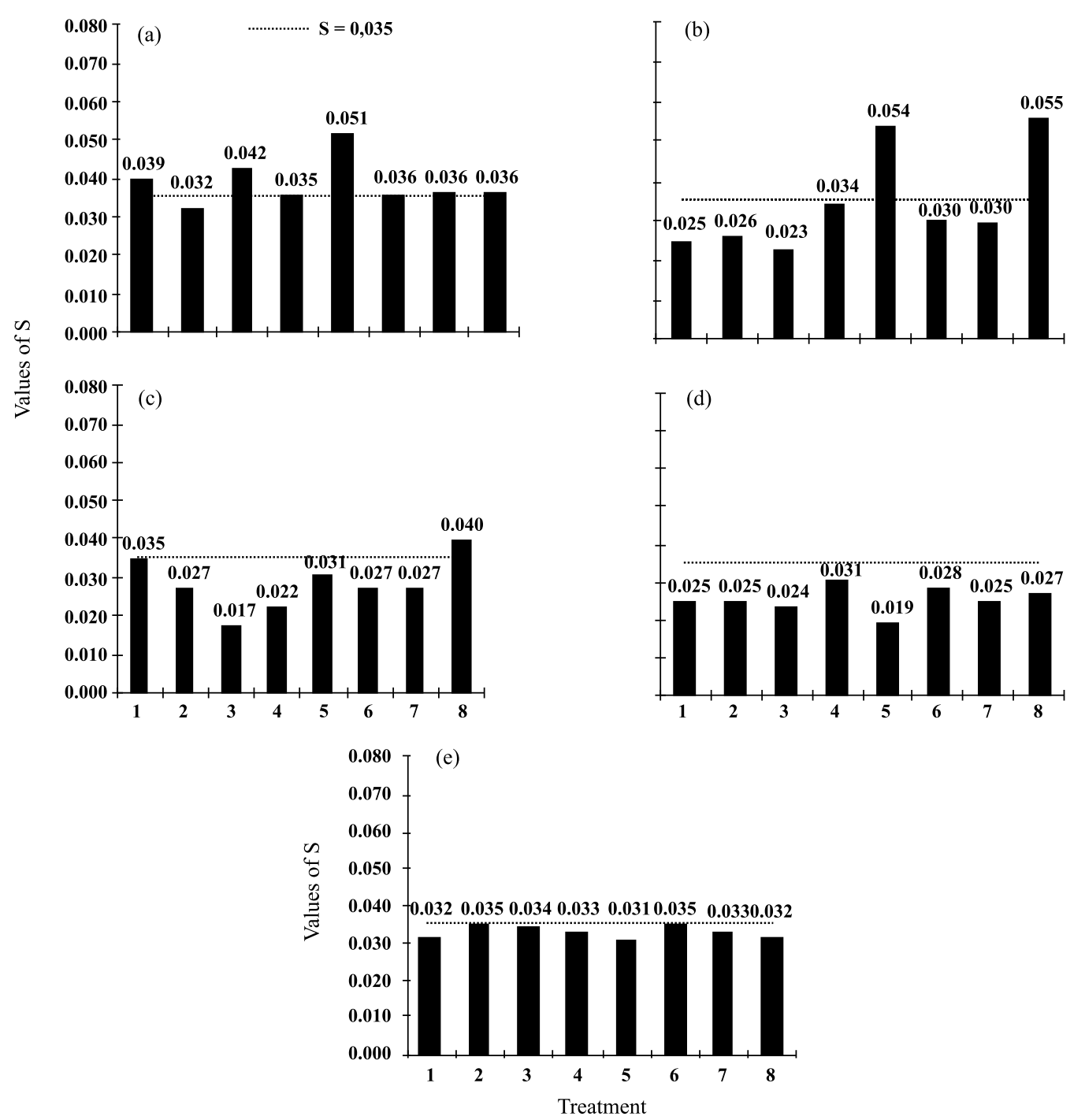

Figure 4. S values observed after cover crop desiccation in the first year of the experiment (2003/2004) as affected by soil depth. (a) 0-0.05 m; (b) 0.075-0.125 m; (c) 0.15-0.20 m; (d) 0.275-0.325 m and (e) 0.475$0.525 \mathrm{~m}$. Treatments: 1) sunflower + pearl millet; 2) sunflower + sorghum; 3) sunflower + sunn hemp; 4) sunflower + chiseling; 5) triticale + pearl millet; 6) triticale + sorghum; 7) triticale + sunn hemp and 8) Triticale + chiseling.

the PWP. Conversely, sorghum, especially in succession to triticale, resulted in greater water retention at medium and high tensions, indicating greater soil compaction in this layer. The highest $S$ index value in this layer (Figure 5c) was obtained under triticale plus sunn hemp $(S=0.070)$, and the lowest for triticale plus sorghum $(S=0.040)$.

There was lower water retention at tensions over $100 \mathrm{hPa}$ with chiseling in the $0.275-0.325 \mathrm{~m}$ layer (Figure $4 \mathrm{~d}$ ). This shows a smaller volume of capillary and hygroscopic water, suggesting that chiseling effects persisted down to the maximum depth of action of the equipment, even after three years, because these results are typical of soils with a lower proportion of micropores. Triticale plus chiseling resulted in the greatest $S$ value, that is, $S=0.041$ (Figure $5 \mathrm{~d}$ ). The greater effect of chiseling on loosening the soil profile may be related to the low root colonization in these layers, which reduces the effects of cover crops on soil structure. Furthermore, there is less reorganization of soil particles in this layer since the loads applied to the surface are dissipated in the first centimeters of the profile, in addition to a lower intensity of the wetting and drying cycles, indicating that the soil remains moist for a longer time at this depth.

Great similarity was observed among water retention curves in the 0.475-0.552 m layer (Figure 4e) probably because the roots had little influence and chisel plow shanks did not reach this depth. In this layer, the $S$ values calculated ranged from 0.020 to 0.035 (Figure 5e), which according to Dexter (2004), indicate poor soil physical quality. 


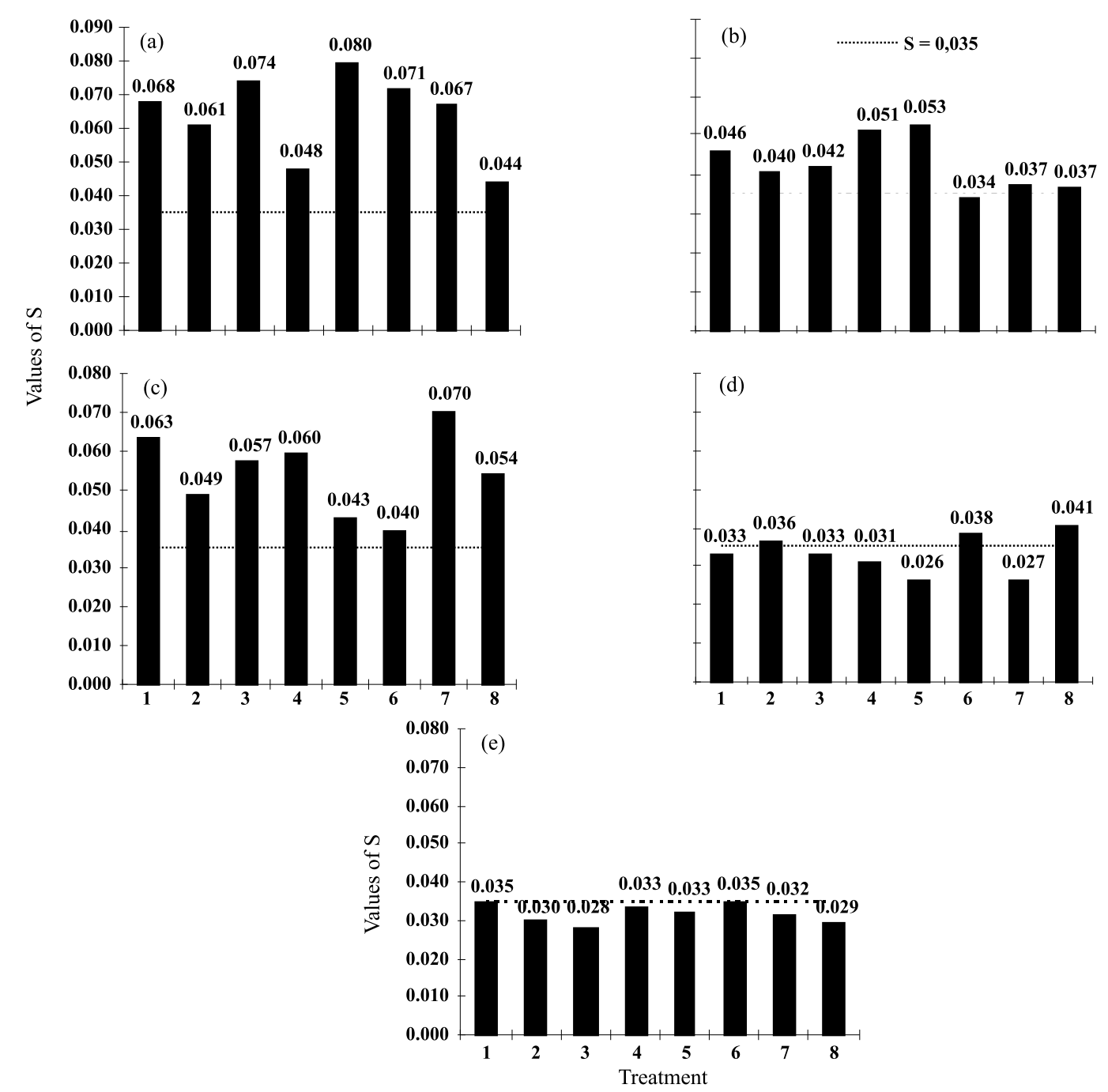

Figure 5. S values observed after cover crop desiccation in the third year of the experiment (2005/2006) as affected by soil depth. (a) 0-0.05 m; (b) 0.075-0.125 m; (c) 0.15-0.20 m; (d) 0.275-0.325 m and (e) 0.475$0.525 \mathrm{~m}$. Treatments: 1) sunflower + pearl millet; 2) sunflower + sorghum; 3) sunflower + sunn hemp; 4) sunflower + chiseling; 5) triticale + pearl millet; 6) triticale + sorghum; 7) triticale + sunn hemp and 8) Triticale + chiseling.

\section{CONCLUSIONS}

1. Crop rotation and chiseling improved soil quality, increasing the $S$ index to over 0.035 , down to a depth of $20 \mathrm{~cm}$ in the soil profile. However, the greatest alterations in the soil physical quality were observed in the 0-0.05 m layer and the lowest $S$ values were obtained in the treatments with chiseling and without cover crops.

2. Cropping pearl millet in succession to triticale improved the soil structural quality to a depth of $0.125 \mathrm{~m}$ from the very first year on, but sunn hemp in succession to triticale improved the physical quality at a greater depth $(0.15$ to $0.20 \mathrm{~m})$ after three years.

3 . The $S$ values observed after three years did not justify the use of chiseling since no-tillage cover crops led to similar soil profile improvements.

\section{ACKNOWLEDGEMENTS}

This research was funded by FAPESP (State of São Paulo Research Foundation)

\section{LITERATURE CITED}

ANDRADE, R. S. \& STONE, L.F. O índice S como indicador da qualidade física de solos do Cerrado brasileiro. R. Bras. Eng. Agric. Amb., 13:382-388, 2009.

ANDREOLA, F.; COSTA, L.M. \& OLSZEVSKI, N. Influência da cobertura vegetal de inverno e da adubação orgânica e, ou, mineral nas propriedades físicas de uma Terra Roxa Estruturada. R. Bras. Ci. Solo, 24:857-865, 2000.

CAlonego, J.C. \& ROSOlEM, C.A. Estabilidade de agregados do solo após manejo com rotações de culturas e escarificação. R. Bras. Ci. Solo, 32:1399-1407, 2008. 
CALONEGO, J.C. \& ROSOLEM, C.A. Soybean root growth and yield in rotation with cover crops under chiseling and no-till. Europ. J. Agron., 33:242-249, 2010.

CAVALIERI, K.M.V.; TORMENA, C.A.; VIDIGAL FILHO, P.S.; GONÇALVES, A.C.A. \& COSTA, A.C.S. Efeitos do sistema de manejo nas propriedades físicas de um Latossol Vermelho distrófico. R. Bras. Ci. Solo, 30:137-147, 2006.

CAVALIERI, K.M.V.; SILVA, A.P.; TORMENA, C.A.; LEÃO, T.P.; DEXTER, A.R. \& KÄKANSSON, I. Long-term effects of no-tillage on dynamic soil physical properties in a Rhodic Ferrasol in Paraná, Brazil. Soil Tillage Res., 103:158-164, 2009 .

DEXTER, A.R. Soil physical quality: Part I. Theory, effects of soil texture, density, and organic matter, and effects on root growth. Geoderma, 120:201-214, 2004.

DIAS JÚNIOR, M.S. Compactação do solo. In: NOVAIS, R.F.; ALVAREZ V., H.V. \& SCHAEFER, C.E.G.R. Tópicos em ciência do solo. Viçosa, MG, Sociedade Brasileira de Ciência do Solo, 2000. v.1 p.55-94.

DOURADO NETO, D.; JONG van LIER, Q.; BOTREL, T.A. \& LIBARDI, P.L. Programa para confecção da curva de retenção de água no solo utilizando o modelo de van Genuchten. Eng. Rural, 1:92-102, 1990.

EMPRESA BRASILEIRA DE PESQUISA AGROPECUÁRIA EMBRAPA. Centro Nacional de Pesquisa de Solos. Sistema brasileiro de classificação de solos. 2.ed. Rio de Janeiro, 2006. 306p.

EMPRESA BRASILEIRA DE PESQUISA AGROPECUÁRIA EMBRAPA. Serviço Nacional de Pesquisa do Solo. Manual de métodos de análises de solo. Rio de Janeiro, 1997. $321 \mathrm{p}$.

FAO. Guidelines for Soil Profile Description. Third edition (revised). Soil Resources, Management and Conservation Service, Land and Water Development Division, FAO, Rome. 1990. 70p.

KLUTE, A. Water retention: Laboratory methods. In: KLUTE, A., ed. Methods of soil analysis. 2.ed. Madison, ASA, 1986 Part. 1. p.635-662.

KÖPPEN, W. Grundriss der Klimakunde. Berlin, Walter de Gruyter, 1931. 390p.
LIMA, C.L.R.; SILVA, A.P.; IMHOFF, S. \& LEÃO, T.P. Compressibilidade do solo sob sistemas de pastagem irrigada e não irrigada. R. Bras. Ci. Solo, 28:945-951, 2004.

RAIJ, B.van; ANDRADE, J.C.; CANTARELLA, H. \& QUAGGIO, J.A. Análise química para avaliação da fertilidade de solos tropicais. Campinas, Instituto Agronômico de Campinas, 2001. 284p.

REEVE, J.M. \& CARTER, A.D. Water release characteristics. In: SMITH, K.A. \& MULLINS, C.E., eds. Soil analysis: Physical methods. New York, M. Dekker, 1991. p.111160.

REICHARDT, K. \& TIMM, L.C. Solo, planta e atmosfera: Conceitos, processos e aplicações. Barueri, Manole, 2004. $312 \mathrm{p}$.

SCHAEFER, C.E.G.R.; SILVA, D.D.; PAIVA, K.W.N.; PRUSKI, F.F.; ALBUQUERQUE FILHO, M.R. \& ALBUQUERQUE, M.A. Perdas de solo, nutrientes, matéria orgânica e efeitos micro-estruturais me um Argisolo Vermelho-Amarelo sob chuva simulada. Pesq. Agropec. Bras., 37:669-678, 2002.

SILVA, A.P.; KAY, B.D. \& PERFECT, E. Characterization of the least limiting water range. Soil Sci. Soc. Am. J., 58:1775-1781, 1994.

SILVA, R.H. \& ROSOLEM, C.A. Crescimento radicular de plantas de cobertura em função da compactação do solo. R. Bras. Ci. Solo, 25:253-260, 2001.

SMITH, K.A. \& MULLINS, C.E. Soil analysis: Physical methods. New York, M. Dekker, 1991.

SPERA, S.T.; SANTOS, H.P.; FONTANELI, R.S. \& TOMM, G.O. Efeitos de sistemas de produção de grãos envolvendo pastagens sob plantio direto nos atributos físicos de solo e na produtividade. R. Bras. Ci. Solo, 28:533-542, 2004.

TORMENA, C.A.; SILVA, A.P.; IMHOFF, S.C. \& DEXTER, A.R. Quantification of the soil physical quality of a Tropical Oxisol using the S index. Sci. Agric., 65:56-60, 2008.

van GENUCHTEN, M.T. A closed-form equation for predicting the hydraulic conductivity of unsaturated soils. Soil Sci. Soc. Am. J., 44:892-897, 1980. 
